\title{
AN ANALYSIS OF TRANSLATION TECHNIQUES AND QUALITY IN TERMS OF ACCURACY, ACCEPTABILITY AND READABILITY OF PI'S EXPRESSIVE SPEECH ACT IN THE FILM ENTITLED LIFE OF PI
}

\author{
By: \\ Vibry Andina Nurhidayah \\ Master Program of Linguistics Department; \\ Postgraduate Program, Sebelas Maret University \\ E-mail: vibry_an@yahoo.com
}

\begin{abstract}
This research was conducted to analysis the translation techniques and quality of types on expressive speech acts exploited by $\mathrm{Pi}$, the main character in the film "Life of PI". The research used the Pragmatics approach with speech act as the field of study. It was a descriptive qualitative research and it employed purposive sampling as the sampling technique. The data in this research were the types of expressive speech acts. From the result of data analysis, there are four types of expressive speech acts employed by Pi character in the film "Life of PI", they are thanking, apologizing, blaming and praising. From the analysis, the first finding of the research shows that the total data of research are 24 data. There are four expressive, thanking expressive speech act 7 data, apologizing speech act 10 data, blaming 3 data, and praising 4 data. The second finding of the research shows that there are two techniques employed by the translator in translating expressive speech act in the film "Life of Pi". They are literal translation 19 data and explicit translation 5 data. The third finding dealing with the quality of translation, the translation of expressive speech act in the subtitle film "Life of Pi" belongs to accurate and acceptable and readable translation. For the accuracy of the translation, from 24 data, 19 data are accurately translated, 5 data are less accurately translated. For the acceptability of the translation, from 24 data, 21 data are acceptably translated, 3 data are less acceptably translated. For the readability, all the 24 data are readable.
\end{abstract}

\section{INTRODUCTION}

Life of PI is an originated from 2001 novel 'Life of PI'. It is also based on Bookerprize winning novel Life of Pi by Canadian author Yann Martel. It tells about a man named Pi (Suraj Sharma) tells a story that occurred when he was 16 . When his family decides to move their zoo from India to Canada, Pi winds up as the only human survivor of the tragic sinking of a cargo ship. On the sea in a lifeboat, he's accompanied by the other survivors-a 
zebra, a hyena, a female orangutan and a 450-pound aggressive Bengal tiger named Richard Parker. Pi tries catching fish to feed the tiger so he won't get eaten himself.

In 'Life of PI', Pi (Suraj Sharma) is the main character of the film. The expressive expression is used the most of the Pi character. The chosen utterances in conversation can tell and reflect his character. The interesting aspect of analyzing expressive speech acts uttered by Pi character in this film can tell and contribute to reflect Pi character building as a young boy who tries to survive in the middle of the ocean. Based on this reason, the researcher is interesting in analyzing expressive speech acts taken by Pi character in 'Life of PI' film.

People need to communicate to each other to fulfill their own needs. They communicate to express their ideas, thought, and feeling. Communication is understood as the exchange of information between at least two individuals through the use of verbal and non-verbal symbols, oral and written or visual modes and comprehension process (Richards and Schmidt, 1984:4). To achieve the aim of communication there must be speakers and hearers. The communication will run well if both speakers and hearers are able to deliver and understand thoughts, feelings and desire one another.

In daily conversation, a speaker is not only producing utterances containing grammatical structures and words, but also performing actions through the utterances. Actions performed via utterances are generally called speech acts (Yule, 1996:47). People perform speech acts when they offer an apology, greeting, request, refusal, etc. There are five basic kinds of action that one can perform in speaking, by means of the following five types utterances, they are representatives, directives, commisives, expressive, and declaration ( Searlee, 1985).

As one of the classification of speech acts that often occurs in the conversation between one person to another is expressive. Expressive is one type of speech acts in which the speakers express their feeling. According to Huang, expressive are those kinds of speech act that express a psychological attitude or state in the speaker such as joy, sorrow, and likes/dislikes. Paradigmatic cases include apologizing, blaming, congratulating, praising and thanking.

Expressive speech acts is expressions which based on psychological state and relate to the expression of speaker's feeling upon the hearer. There are some strategies in uttering the expressive expression by each other speaker. It can be influenced by the goal of utterance, the speaker and the hearer, and the status between them. The strategies can be verbal which 
means that the speaker utters direct or indirect speech act, explicit or implicit statement, in high or low intonation, while the non-verbal strategy can be showed through the body movement, facial expression, eyes gaze, or gesture. Those strategies are used to give the force of the degree of strength of their expressive speech acts.

Next, the audience can get the Pi character, if they understand the meaning of expressive speech acts used by Pi in the film. Luckily, the subtitling will become the solution of the meaning problem. The interesting part is how the expressive speech acts uttered by Pi are translated into target language. For that reason, the researcher analyzes the expressive speech acts and their translation in the subtitle text 'Life of PI' to find the techniques applied by the translator and the quality translation of expressive speech acts in terms accuracy, acceptability and readability of the translation.

The below conversations show the examples of expressive in the 'Life of PI' film :

1. SL:

Man : 2 years trying to bring this thing to life. And then one day, it sputtered, coughed and died.

Pi : oh, I am sorry.

2. TL:

Man : Dan suatu hari, segalanya

Terasa salah dan kucampak'kan.

Pi : oh, maafkan aku.

The example above is one of the apology expressive speech act. Pi utters an apology speech act by saying "oh, I am sorry". The translation can be considered accurate. It means that the message of the apology expressive speech act is accurately conveyed into the target language.

3. SL:

$\mathrm{Pi}$ : thank you, Vishnu, for introducing me to Christ.

TL:

Pi : terima kasih wisnu, karena mengenalkanku dengan Kristus. 
The second example is categorized as a thanking because Pi intends to express her grateful to Vishnu for introduces him to Christ. The translation is accurate conveyed into target language.

The various types of expressive uttered by $\mathrm{Pi}$ is an interesting point to observe. Based on this reason, the researcher is interested to discuss about the types of expressive speech acts uttered by the main character, how they are exploited by the main character, and how techniques and quality of the expressive speech acts translated in the film to reflect Pi character as the main character in the film.

\section{THEORETICAL REVIEW}

\subsection{Pragmatics}

Conversation is used by people to communicate with others. When they convey words or sentences, they have certain intention behind their utterances. Pragmatics belongs to one of linguistic branches. It focuses its study of utterances. Nadar (2009:2) states that pragmatics is the linguistic branch studying about usage to communicate in a certain situation, while Yule (1996:3) states pragmatics is concerned with the study of meaning as communicated by a speaker (or writer) and interpreted by a listener (or reader). It can be concluded that pragmatics is concerned with the meaning of an utterance, in which the meaning depends on the situation where the utterance occurs.

Pragmatics deals with how listeners can make inferences about what is said in order to arrive at an interpretation of speaker's intended meaning. This type of study explores how a great deal of what is unsaid is recognized as part of what is communicated. Another perspective is that pragmatics deals with the ways we reach our goal in communication. To reach the goal of communication there must be speakers and the hearers are able to convey and to understand thoughts, feelings, and desire each other.

\subsection{Expressive Speech Acts}

People commit a variety of speech acts to achieve their goal in communication. Searle purposes the types of speech acts into five major classes, they are representatives, directives, commisives, expressive and declaration (Huang, 2007). One of those classifications is expressive. Expressive are those kinds of speech acts based on psychological states and relate to the expression of feelings or emotion to the hearer. It means the speaker expresses feeling towards the hearer. There are several types of expressive forms such as apologizing, blaming, congratulating, praising and thanking. In expressive there is no direction of fit. In performing 
an expressive, the speaker is neither trying to get the world to match the words nor the words to match the world; rather the truth of expresses proposition is presupposed.

In using an expressive, the speaker makes known what he or she feels, thus rendering the words to fit the world of feeling (Yule,1996). When people perform expressive, they may say their speech by using performative verbs. Performative verbs are the verbs showing the type of speech act explicitly. Those speech acts can be affirmed by the non verbal expression via facial expression, eyes gazed, body movement, or gesture.

The expressive are differentiated into some types, apologizing is a statement saying that you are sorry for having done wrong, hurt somebody's feelings, etc. it is verbal commitment by one person to another to express and make an apology, acknowledge failing or faults and also to make a formal defense in speech or writing. Leech in Trosborg (1995) said that the act of apologizing is convivial speech act, the goal of which coincides with the social goal of maintaining harmony between speaker and hearer. Blaming is a statement to feel or declare that someone or something is responsible for a fault or wrongdoing. It means that the utterance is used to hold responsible, find fault with, censure. Praising is used to express commendation, admiration, etc. it is also used to proclaim or describe the glorious attributes. Thanking is an utterance to express to someone that you are pleased about/are grateful for something that they have done. In speech act theory, the speech act of thanking is defined as an expression of gratitude and appreciation (Searle,1969). The goal of this utterance is to express gratitude, appreciation, or acknowledgement to God or someone.

\subsection{Translation}

Translation is a transfer process which aims at the transformation of a written SL text into an optimally equivalent TL text, and which requires the syntactic, the semantic and pragmatic understanding and analytical processing of the SL (Wills in Suryadinata, 2003).

Translation techniques is defined as procedures to analyze and classify how translation equivalence works (Molina and Albir, 2002).

Molina and Albir (2002) offer eighteen translation techniques. They are addition, deletion, explicit, implicit, modulation, transposition, generalization, particularization, pure borrowing, borrowing, established equivalence, literal, compensation, calque, description, creation, substitution, variation. 
Translation quality assessment is similar to translation criticism. Newmark (1988) stated that "translation criticism is an essential link between translation theory and practice". It means that, in criticizing a translation product, there is always a relationship between the theory of translation and the application of the theory. The translation quality can be judged in three aspects. The first aspect is accuracy that indicates how faithfully the message of the source text is maintained in the target text. The second aspect is the acceptability that refers to the consistency of the translation to the grammar and culture of the target language. The third aspect is the readability showing the understanding of the target readers to the translation.

The accuracy, acceptability and readability of translation based on the scales below:

Table 1

Scale of accuracy score

\begin{tabular}{|c|l|l|}
\hline Scale & \multicolumn{1}{|c|}{ Categorize } & \multicolumn{1}{c|}{ Indicators } \\
\hline 3 & Accurate & $\begin{array}{l}\text { The meaning or message in words, phrase is } \\
\text { accurately conveyed into the target language. }\end{array}$ \\
\hline 2 & Less accurate & $\begin{array}{l}\text { The meaning or message in words, phrase is less } \\
\text { accurately conveyed into the target language. }\end{array}$ \\
\hline 1 & Inaccurate & $\begin{array}{l}\text { The meaning or message in words, phrase is not } \\
\text { accurately conveyed into the target language. }\end{array}$ \\
\hline
\end{tabular}

(Adopted from Nababan,et. al., 2012)

Table 2

Scale of acceptability score

\begin{tabular}{|c|l|l|}
\hline Scale & \multicolumn{1}{|c|}{ Categorize } & \multicolumn{1}{|c|}{ Indicators } \\
\hline 3 & Acceptable & $\begin{array}{l}\text { The meaning or message in words, phrase is } \\
\text { acceptable culturally, grammatically, and } \\
\text { contextually in target language. }\end{array}$ \\
\hline 2 & Less acceptable & $\begin{array}{l}\text { The meaning or message in words, phrase is less } \\
\text { acceptable culturally, grammatically, and } \\
\text { contextually in target language. }\end{array}$ \\
\hline 1 & Unacceptable & $\begin{array}{l}\text { The meaning or message in words, phrase is } \\
\text { unacceptable culturally, grammatically, and } \\
\text { contextually in target language. }\end{array}$ \\
\hline
\end{tabular}

( adopted from Nababan,et.al., 2012) 
Table 3

Scale of readability score

\begin{tabular}{|c|l|l|}
\hline Scale & \multicolumn{1}{|c|}{ Categorize } & \multicolumn{1}{c|}{ Indicators } \\
\hline 3 & Readable & $\begin{array}{l}\text { The meaning or message in words, phrase is } \\
\text { readable into the target language. }\end{array}$ \\
\hline 2 & Less readable & $\begin{array}{l}\text { The meaning or message in words, phrase is less } \\
\text { readable, the reader has to read more than one time } \\
\text { into the target language. }\end{array}$ \\
\hline 1 & Unreadable & $\begin{array}{l}\text { The meaning or message in words, phrase is not } \\
\text { readable into the target language. }\end{array}$ \\
\hline
\end{tabular}

( adopted from Nababan, et.al., 2012)

\section{METHODOLOGY}

Twenty four expressive utterances were collected from a film entitled Life of PI. They are classified as thanking, apologizing, blaming, and praising. All the data were utterances executed by the main character Pi. After classified into their speech act sub-classification, the utterances were then analyzed to see the quality of their translation version by seeing the techniques and their impact to the accuracy, the acceptability as well as the readability.

\section{ANALYSIS}

The analysis divided into three parts. First is domain analysis, second is taxonomy analysis and the third is componential analysis.

\subsection{Domain Analysis}

Expressive speech acts have many types such as condoling, praising, blaming, congratulating, thanking, etc. the speech acts performed by Pi in the film "Life of PI" are thanking, apologizing, blaming and praising. Then, how the expressive exploited by Pi describe and analyze here. Each type is analyzed below:

\subsubsection{Thanking}

The term thanking is the utterance which is used by the speakers to express their grateful for something that the hearer's has done. The speaker has the goal when she conveys a thanking speech act that is to express gratitude or appreciation to the hearer. In uttering a thanking, the speakers usually use word "Thank you". The data belonging to Thanking employed by Pi character in the movie explained as below:

Pi :Thank you Vishnu, for introducing me to Christ. 
Pi :Terima kasih Wisnu, karena mengenalkanku dengan Kristus.

Pi says "Thank you Vishnu”. He intends to express his grateful to Vishnu who introduced him to Christ. In this case, Pi uses the word "Thank you" to express his gratitude. Pi expresses his gratitude in the form of direct speech act in low intonation to show how grateful he is and he also uses non-verbal expressions such as through his body by nodding his head and closes his eyes.

Pi :Thank you Lord Vishnu. Thank you for coming in the form of a fish and saving our lives.

Pi :Terima kasih Dewa Wisnu. Terima kasih telah datang padaku dalam bentuk ikan dan menyelamatkan nyawa kami.

The data above shows that Pi utters a thanking to Lord Vishnu for the fish, by saying "Thank you Lord Vishnu. Thank you for coming in the form of a fish and saving our lives."'The utterance categorized as a thanking speech act because the speaker intends to express his appreciation to Lord Vishnu for the help. Pi says thank to Vishnu in high intonation showing his enthusiastic about the fish. In uttering his thank, he also uses his non-verbal expressions in his eyes gaze and his facial expression which show that he is thankful while smiling and nodding his head.

\subsubsection{Apologizing}

The term of apology means that the speakers express their feeling of having done wrong or hurt somebody's feeling. It is verbal commitment by one person to another to express and make an apology, acknowledge failing or faults. In uttering apology the speakers usually use the sentence "I'm sorry". the data belong to apology employed by Pi character in the movie are explained below:

Pi : Amma! Appa! Ravi! ... I am sorry.

Pi : Mama! Papa! Ravi!...aku minta maaf.

The data above shows that an apology speech act is uttered by Pi to his parents and Ravi. He utters an apology because he could not safe their life. Pi utters an apology by saying “ Amma! Appa! Ravi! ..I am sorry” so that it can be categorized as an apology speech act. He says his apology in the form of direct speech act by saying “Amma! Appa! Ravi!..I am sorry!(CRYING), showing his regret, his speech act is uttered explicitly in high intonation to convince and to show the strength of his apology.

Pi : We're dying Richard Parker. I am sorry. 
Pi : Kita sekarat Richard Parker. Maafkan aku.

The data shows that an apology is delivered by $\mathrm{Pi}$ as the speaker to Richard Parker as the hearer. The utterance is categorized as an apology speech act because Pi intends to apology that he couldn't do anything to help themselves to survive from the hunger in the middle of the ocean. Pi says his apology in the form of direct speech act. He says "I am sorry" to Richard Parker in low intonation to convince and to show the weakness of his intention. His eye gaze shows sadness while uttering an apology.

Amma : You know what your father said about coming back here.

$\mathrm{Pi}$ : I am sorry,..

Amma : Kau tahu perintah ayahmu tentang datang kemari.

Pi : Maafkan aku...

The dialogue above shows that an apology uttered by Pi by saying "I am sorry". the utterance is categorized as an apology speech act because Pi intends to apologize to her mother for coming back to the Richard Parker cave without his father permission. Pi says his apology to his mother in the form of direct speech in low intonation by saying "I am sorry". His eye gaze and facial expression also show that his apology is stated seriously and sincerely.

\subsubsection{Blaming}

The term blaming means that the speakers have intention to say that someone or something did something wrong. It usually occurs in a situation in which people declare someone or something for a fault or wrong doing. The message of blaming is conveyed directly to the hearer. In uttering a blaming the speaker may use the performative verb "blame" or not. The data belong to blaming speech act employed by Pi character in the movie are explained below:

Pi :Because of me. Because I couldn't hold on to a stupid turtle.

Pi : Karena aku. Karena aku tidak bisa memegang seekor penyu bodoh.

The conversation above shows that $\mathrm{Pi}$ blames himself by his statement "because of me." $\mathrm{Pi}$ as the speaker intends to blame himself to the hearer. $\mathrm{He}$ expresses his belief about his mistaken. Consequently, the utterance is categorized as a blaming speech act. Pi utters "Because of me. Because I couldn't hold on to a stupid turtle" in form of direct speech act in the form of statement. He also performs his 
utterance in high intonation and continuing his statements by explanation his mistaken.

\subsubsection{Praising}

The term praising is the expression of admiration, commendation, or approval. Praise indicates a person's positive attitude, provide recognition and encouragement. It is one of the most effective ways of rewarding people for their efforts and succeeds. It can also increase the praised person's motivation to excel. The data belonging to praising employed by $\mathrm{Pi}$ character in the movie are explained below:

Pi : Richard Parker! Come out, you have to see this! Its beautiful.

Pi : Richard Parker! Keluarlah kau harus melihat ini! Ini indah.

The data above shows that Pi utters a praising by saying "Its beautiful." By using the commendation word "beautiful" the utterance above can be categorized as a praising easily. Pi utters "Praise be to God" in high intonation. His utterance is in the form direct speech act by using statement in imperative form and explaining the reason. In uttering his praise, he uses non-verbal action by showing his eyes gaze and facial expression to show that his praise is stated seriously.

\section{Pi :Praise be to God!}

\section{Pi :Terpujilah Tuhan!}

The data above shows that Pi utters a praising to God by saying "Praise be to God". By using the commendation word "Praise" the utterance above can be categorized as a praising speech act. In uttering his praise, he uses a statement "Praise be to God" in high intonation. His utterance indicates a praising speech act in the form of direct speech act. He also uses non-verbal action by showing his eyes gaze and facial expression to show the strength of his appreciation to God.

\subsection{Taxonomy Analysis}

In producing a good translation, a translator should use a proper technique of translation. In this research, researcher used the translation techniques proposed by Molina and Albir (2002: 509). 


\begin{tabular}{|c|c|c|c|}
\hline No. & SL & TL & TT \\
\hline 1. & $\begin{array}{l}\mathrm{Pi} \text { : Thank you Vishnu, } \\
\text { for introducing me to } \\
\text { Christ. }\end{array}$ & $\begin{array}{l}\mathrm{Pi} \text { : Terima kasih Wisnu, } \\
\text { karena mengenalkanku } \\
\text { dengan Kristus. }\end{array}$ & Literal \\
\hline 2. & $\begin{array}{l}\text { Pi :Thank you Lord } \\
\text { Vishnu. Thank you for } \\
\text { coming in the form of a } \\
\text { fish and saving our lives. }\end{array}$ & $\begin{array}{l}\text { Pi :Terima kasih Dewa } \\
\text { Wisnu. Terima kasih telah } \\
\text { datang padaku dalam bentuk } \\
\text { ikan dan menyelamatkan } \\
\text { nyawa kami. }\end{array}$ & Literal \\
\hline 3. & $\begin{array}{l}\text { Pi : amma! Appa! Ravi! } \\
\text {... I am sorry. }\end{array}$ & $\begin{array}{l}\mathrm{Pi} \text { : mama! Papa! Ravi!...aku } \\
\text { minta maaf. }\end{array}$ & Literal \\
\hline 4. & $\begin{array}{l}\text { Pi : we're dying Richard } \\
\text { Parker. I am sorry. }\end{array}$ & $\begin{array}{l}\mathrm{Pi} \text { : kita sekarat Richard } \\
\text { Parker. Maafkan. }\end{array}$ & Explicit \\
\hline 5. & $\begin{array}{l}\text { Amma : you know what } \\
\text { your father said about } \\
\text { coming back here. } \\
\text { Pi :I am sorry,.. }\end{array}$ & $\begin{array}{l}\text { Amma : kau tahu perintah } \\
\text { ayahmu tentang datang } \\
\text { kemari. } \\
\text { Pi :maafkan aku... }\end{array}$ & Literal \\
\hline 6. & $\begin{array}{l}\mathrm{Pi} \text { :because of me. } \\
\text { Because I couldn't hold } \\
\text { on to a stupid turtle. }\end{array}$ & $\begin{array}{l}\mathrm{Pi} \text { :karena aku. Karena aku } \\
\text { tidak bisa memegang seekor } \\
\text { penyu bodoh. }\end{array}$ & Literal \\
\hline 7. & $\begin{array}{l}\mathrm{Pi}: \text { Richard Parker! } \\
\text { Come out, you have to } \\
\text { see this! Its beautiful }\end{array}$ & 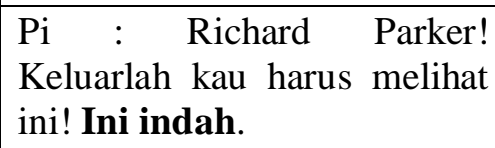 & Literal \\
\hline 8. & Pi :praise be to God! & $\mathrm{Pi}$ :terpujilah Tuhan! & Literal \\
\hline 9. & $\begin{array}{l}\text { Appa: do you } \\
\text { understand? } \\
\text { Pi: I am sorry, what are } \\
\text { we talking about? }\end{array}$ & $\begin{array}{l}\text { Appa : kau paham apa yang } \\
\text { kubicarakan? } \\
\text { Pi : maaf, kau? }\end{array}$ & Explicit \\
\hline 10. & $\begin{array}{l}\text { Man: that's the better } \\
\text { story. } \\
\text { Pi : thank you. }\end{array}$ & $\begin{array}{l}\text { Man : kisah itu lebih baik. } \\
\text { Pi :terima kasih. }\end{array}$ & Literal \\
\hline
\end{tabular}




\subsection{Componential Analysis}

\begin{tabular}{|c|c|c|c|c|c|c|c|c|c|c|}
\hline \multirow{3}{*}{ TT } & \multirow{3}{*}{ Expressive } & \multicolumn{9}{|c|}{ Translation Quality } \\
\hline & & \multicolumn{3}{|c|}{ Accuracy } & \multicolumn{3}{|c|}{ Acceptability } & \multicolumn{3}{|c|}{ Readibility } \\
\hline & & Acc & Less & In & Acc & Less & Un & Read & Less & Un \\
\hline \multirow{4}{*}{ Literal } & Thanking & 4 & - & - & 4 & - & - & 4 & - & - \\
\hline & Apologizing & 8 & 1 & - & 9 & - & - & 9 & - & - \\
\hline & Blaming & 2 & - & - & - & 2 & - & 2 & - & - \\
\hline & Praising & 4 & - & - & 4 & - & - & 4 & - & - \\
\hline \multirow{4}{*}{ Explisit } & Thanking & - & 3 & - & 3 & - & - & 3 & - & - \\
\hline & Apologizing & 1 & - & - & - & 1 & - & 1 & - & - \\
\hline & Blaming & 1 & - & - & 2 & 1 & - & 1 & - & - \\
\hline & Praising & - & - & - & - & - & - & - & - & - \\
\hline
\end{tabular}

\section{Conclusion}

From the data analysis, the types of expressive that are employed by Pi character in the film "Life of Pi" are thanking, apologizing, blaming and praising. When the speakers perform expressive speech acts, those speech acts have certain functions. When Pi says apologizes, they are expressed to show care, to show the dislike, to avoid conflicts, and to show the regret of what his done to the hearer. Next, when Pi says blames expressive, they are expressed to express the belief and conviction of something, also to express his negative feeling and anger to the hearer. Besides, praise is expressed to reward the hearer's efforts and to increase the hearer's motivation. The last, thanks are expressed to express Pi's gratitude and appreciation to the hearer, and to close the public speech in formal situation. Then, $\mathrm{Pi}$ uses verbal and non-verbal expression in uttering the expressive. The verbal expression means that Pi uses direct or indirect speech act, explicit or implicit statement, in high, normal, or low intonation in uttering the expressive. Besides, Pi uses explanation of his reason or not in uttering expressive. The non-verbal expression is commonly done through body language to emphasize his speech acts which is performed via eyes gaze, facial expression (happy, sad, annoyed, angry, disappointed and anger), and body movement (nodding and bowing his head). From the explanation above, conclude that $\mathrm{Pi}$ is a care and responsible character by his utterance and he has a big appreciation of something, especially to his God.

From the analysis, the first finding of the research shows that the total data of research are 24 data. There are four expressive, thanking expressive speech act 7 data, apologizing speech act 10 data, blaming 3 data, and praising 4 data. The second finding of the research 
shows that there are two techniques employed by the translator in translating expressive speech act in the film "Life of Pi". They are literal translation 19 data and explicit translation 5 data. The third finding dealing with the quality of translation, the translation of expressive speech act in the subtitle film "Life of Pi" belongs to accurate and acceptable and readable translation. For the accuracy of the translation, from 24 data, 19 data are accurately translated, 5 data are less accurately translated. For the acceptability of the translation, from 24 data, 21 data are acceptably translated, 3 data are less acceptably translated. For the readability, all the 24 data are readable.

\section{REFERENCES}

Huang, Y. (2007). Pragmatics. New York: Oxford University Press.

Molina, Lucia \& Albir, Amparo Hurtado.2002. Translation Techniques Revisited: A Dynamic and Functionalist Approach. Meta, XLVII,4.

Nababan, dkk.2012.Pengembangan Model Penilaian Kualitas Terjemahan.Surakarta: Universitas Sebelas Maret.

Nadar, FX. (2009). Pragmatic dan penelitian pragmatic. Yogyakarta: Graha Ilmu.

Newmark, Peter. 1988. A Textbook of Translation. Hertfordshire: Prentice Hall International.

Richard, J. C., \& Schmidt, R. W. (1996).Language and communication. New York : Addiso Wesley Longman Inc.

Searle, J. R. (1969). Speech acts: an essay in the philosophy of language. Cambridge: Cambridge University Press.

Suryawinata, Zuchridin \& Hariyanto, Sugeng. 2003. Translation: Bahasan Teori\& Penuntun Praktis Menerjemahkan. Yogyakarta:Kanisius.

Trosborg, A. (1995). Interlanguage Pragmatics: requests, complaints, and apologies. Berlin: Mouton de Gruyter.

Yule, George. 1996. Pragmatics. New York: Oxford University Press. 